Artikel History

Submitted: $30 / 03 / 2020$

Revisied: 28/06/2020

Accepted: 29/06/2020
KOMUNITAS: Jurnal Pengembangan Masyarakat Islam

ISSN: 2086-3357 (p); 2540-9182 (e);

Vol.11 No.1 (2020): 079-96, doi; https://doi.org/10.20414/jpk.v16i1.1104 https://journal.uinmataram.ac.id/index.php/komunitas

\title{
SIARAN LAYANAN PUBLIK RADIO MAYANGKARA FM KOTA BLITAR
}

\author{
Rendi Panju \\ Universitas Dr Soetomo \\ redipanju@gmail.com
}

\begin{abstract}
[Abstrak: This study wanted to know and dig deeper about Mayangkara Radio interactive broadcasting program to improve public services in Blitar City with case study of the Lang Lang Kota from Radio Mayangkara FM Blitar. This is behind Lang Lang Kota as the pioneer of interactive broadcasting in Blitar which has been able to survive until now by presenting the concept of citizen journalism. This type of research is qualitative research with a case study method. The method of data collection is done by conducting observations, interviews and documentation. The results showed that the Lang Lang Kota interactive broadcasting program was a public space while maintaining neutrality in its broadcasts. Participation, public awareness of public services and reciprocity provided by institutions or public service providers become the main force in the Lang Lang Kota interactive broadcasting. In accordance with its slogan, critically solutive, Lang Lang Kota responds to a variety of information and cases that are delivered critically and seeks solutions. Radio Mayangkara through Lang Lang Kota also educates the public in expressing opinions or criticizing a problem according to journalistic rules because it is part of the function of the mass media]
\end{abstract}

[Penelitian ini ingin mengetahui san menggali lebih dalam mengenai program siaran interaktif Radio Mayangkara untuk meningkatkan pelayanan publik di Kota Blitar dengan studi kasus program Lang Lang Kota Radio Mayangkara FM. Hal ini dilatarbelakangi Lang Lang Kota sebagai pelopor siaran interaktif di Kota Blitar yang mampu bertahan sampai saat ini dengan menghadirkan konsep citizen journalism. Jenis penelitian yan digunakan adalah penelitian kualitatif dengan metode studi kasus. Metode pengumpulan data dilakukan dengan melakukan observasi, wawancara dan dokumentasi. Hasil penelitian menunjukkan bahwa Program siaran interaktif Lang Lang Kota merupakan ruang publik dengan tetap mengedepankan netralitas dalam siarannya. Peran serta, kepedulian masyarakat terhadap layanan publik dan timbal balik yang diberikan instansi atau lembaga penyedia layanan publik menjadi kekuatan utama dalam siaran interaktif Lang Lang Kota. Sesuai dengan slogannya kritis solutif, Lang Lang Kota menanggapi berbagai informasi dan kasus yang disampaikan dengan kritis dan mengupayakan adanya solusi. Radio Mayangkara melalui Lang Lang Kota juga mengedukasi masyarakat dalam menyampaikan pendapat atau mengkritisi sebuah permasalahan.] 
Redi Panju

Keywords: Interactive Broadcasting, Public Sphere, Public services, Lang Lang Kota, Radio Mayangkara

\section{A. Pendahuluan}

Media massa memiliki peran penting dalam kehidupan negara dan masyarakat. Melalui media, beragam informasi, opini, gagasan dan kritikan atau masukan saling dipertukarkan. Dengan adanya sharing informasi dan aspirasi tersebut, media diharapkan mampu menciptakan keseimbangan dalam kehidupan bernegara sehingga menjadi ruang yang potensial untuk menegakkan demokrasi. Beragam persoalan yang dihadapi media massa sebagai ruang publik menjadi salah satu tolak ukur dalam kehidupan demokrasi sebuah negara .

Kebebasan berekspresi dan mengutarakan pendapat merupakan hak setiap warga negara yang dijamin oleh UUD 1945. Hak dasar tersebut harus terpenuhi dan dilindungi dari berbagai intervensi atau kepentingan. Untuk menyampaikan aspirasi inilah warga negara membutuhkan sarana komunikasi yaitu sebuah ruang publik yang mampu menjadi wadah bagi opini maupun kritik mereka terhadap berbagai permasalahan. Pentingnya ruang publik diutarakan oleh Jurgen Habermas, seorang filsuf dan sosiologis dari Jerman yang menegaskan bahwa ruang publik memberikan peran yang penting dalam proses demokrasi di setiap negara. Ruang publik memberikan kesempatan kepada setiap warga negara untuk dapat menyatakan opiniopini, kepentingan-kepentingan dan kebutuhan-kebutuhan mereka secara diskursif. Ruang publik tidak hanya sebagai institusi atau organisasi yang legal, melainkan komunikasi antar warga itu sendiri ${ }^{1}$.

Menurut McQuail dalam bukunya Mass Communication Theories, ada enam perspektif dalam melihat peran media². Pertama melihat media massa sebagai window on event and experience. Media dipandang sebagai jendela yang memungkinkan khalayak melihat apa yang sedang terjadi di luar sana. Atau media

\footnotetext{
${ }^{1}$ F.B Hardiman, Demokrasi Deliberatif: Menimbang 'Negara Hukum' dan 'Ruang Publik' dalam Teori Diskursus Jurgen Habermas, Yogyakarta: Kanisius, 2009.

2 Denis McQuail, Mass Communication Theory, London: Sage, 2000, 66.
}

60 | Komunitas Vol. 11, No. 1 (2020) 
merupakan sarana belajar untuk mengetahui berbagai peristiwa. Kedua, media juga sering dianggap sebagai a mirror of event in society and the world, implying a faithful reflection. Cermin berbagai peristiwa yang ada di masyarakat dan dunia, yang merefleksikan apa adanya. Sehingga para pengelola media sering merasa tidak "bersalah" jika isi media penuh dengan kekerasan, konflik, pornografi dan berbagai keburukan lain, karena memang menurut mereka faktanya demikian, media hanya sebagai refleksi fakta, terlepas dari suka atau tidak suka. Padahal sesungguhnya, angle, arah dan framing dari isi yang dianggap sebagai cermin realitas tersebut diputuskan oleh para profesional media, dan khalayak tidak sepenuhnya bebas untuk mengetahui apa yang mereka inginkan. Ketiga, memandang media massa sebagai filter, atau gatekeeper yang menyeleksi berbagai hal untuk diberi perhatian atau tidak. Media senantiasa memilih isu, informasi atau bentuk content yang lain berdasar standar para pengelolanya. Disini khalayak "dipilihkan" oleh media tentang apa-apa yang layak diketahui dan mendapat perhatian. Keempat, media massa seringkali pula dipandang sebagai guide, penunjuk jalan atau interpreter, yang menerjemahkan dan menunjukkan arah atas berbagai ketidakpastian, atau alternatif yang beragam. Kelima, melihat media massa sebagai forum untuk mempresentasikan berbagai informasi dan ide-ide kepada khalayak, sehingga memungkin terjadinya tanggapan dan umpan balik. Keenam, media massa sebagai interlocutor, yang tidak hanya sekadar tempat berlalu lalangnya informasi, tetapi juga partner komunikasi yang memungkinkan terjadinya komunikasi interaktif.

Melalui siaran interaktif itulah radio siaran sebagai komunikasi massa memiliki potensi membangun jaringan partisipasi pendengar dalam mendiskusikan issu-issu yang menyangkut kepentingan public. Hal itulah yang pada masa pemerintahan Orde Baru (1970-1989), radio memiliki peran penting dalam menyebar luaskan ide-ide baru, khususnya di bidang pertanian. Radio memiliki fungsi sebagai sarana pemberdayaan masyarakat dalam pembangunan. Di era komunikasi digital, peran itu tetap ada 
dengan system siaran konvergensi, yang antara lain ditandai lebih dominannya peran khalayak dan sebaliknya meluruhnya peran negara dalam pengendalian informasi ${ }^{3}$.

Melihat peran penting media massa khususnya media radio bagi negara demokrasi, penelitian ini mengambil fokus pada siaran interaktif program Lang Lang Kota yang disiarkan oleh Radio Mayangkara. Saat pertama kali mengudara pada tahun 1987, lembaga penyiaran swasta pertama di Kota Blitar Jawa Timur ini memilih format sebagai radio hiburan kemudian pada tahun 2000 beralih format menjadi radio news interaktif. Perubahan format itu dilatarbelakangi kondisi sosial politik Indonesia pasca reformasi. Masyarakat semakin sadar akan haknya, menuntut kebebasan dalam berpendapat yang selama Orde Baru terbelenggu dan merekapun lebih menginginkan transparansi terhadap pelayanan publik.

Program siaran Lang Lang Kota Radio Mayangkara FM adalah program siaran utama yang dirancang sebagai ruang publik bagi pendengar (masyarakat) untuk menyampaikan informasi ataupun keluhan terkait pelayanan dan prasarana publik juga permasalahan lainnya. Menurut Haji Hariyanto yang merupakan pemilik Radio Mayangkara, keberadaan Lang Lang Kota mencontoh keberhasilan Program Kelana Kota Radio Suara Surabaya. Diharapkan melalui program Lang Lang Kota mampu memenuhi kebutuhan masyarakat Blitar dan sekitarnya dalam menyampaikan aspirasi, informasi dan opini terkait pelayanan publik yang diperolehnya.

Lang Lang Kota merupakan program siaran interaktif melibatkan penyiar, gatekeeper, narasumber, khalayak atau pendengar dengan berbasis jurnalistik radio. Dalam kegiatan kepenyiaran tersebut, terdapat 14 orang personil yang bertugas sebagai penyiar dan gatekeeper. Rata-Rata dalam satu hari seorang penyiar akan bertugas selama dua jam sebagai gatekeeper dan dua jam selanjutnya sebagai penyiar. Dengan tujuan sebelum memandu Program Lang Lang Kota, semua penyiar telah menguasai topik yang muncul dan beragam persoalan yang disampaikan masyarakat. Yang tidak kalah penting peran dari masyarakat yang bergabung dalam Program Lang Lang Kota (LLK), mereka berfungsi sebagai pendengar atau reporter

\footnotetext{
${ }^{3}$ R Panuju, Pengantar Studi Ilmu Komunikasi, Jakarta: Kencana Prenada Mediagroup, 2018, 133.
} 
yang secara sukarela menyampaikan informasi atau pengaduan terkait pelayanan publik yang tak berjalan sebagaimana mestinya.

Selama melakukan observasi, penulis melihat program LLK mendapat sambutan baik dari masyarakat. Lang Lang Kota yang mengudara sejak pukul 06.0021.00, menjadi tempat orang saling berinteraksi dan menanggapi setiap persoalan mulai dari masalah politik, ekonomi, kriminalitas, isu-isu sosial, budaya, layanan publik dan sebagainya. Pada saat bertugas, para penyiar memberikan topik kemudian pendengar bisa menyampaikan pesan berupa argumen, kritik, ataupun gagasan terkait dengan topik yang sedang dibicarakan melalui telepon atau media sosial berupa whatsaap, instagram atau facebook Radio Mayangkara baik secara on air atau hanya menyampaikan pesan melalui gatekeeper. Selain itu masyarakat juga bebas untuk berinteraksi menyampaikan informasi kepada penyiar seperti dalam konsep citizen journalism. Dalam menjalankan tugas-tugas jurnalistik tersebut baik penyiar ataupun gatekeeper harus melakukan check and recheck, verifikasi data, dan akurasi data dari para pendengar. Edukasi pada masyarakat juga disampaikan melalui kalimat seperti "Yes Fakta No Hoax".

Fokus penelitian ini adalah untuk mengetahui bagaimana bentuk penyajian program siaran interaktif Lang Lang Radio Mayangkara FM dan proses komunikasi yang terjadi antara masyarakat dan lembaga/instansi publik untuk meningkatkan pelayanan publik di Kota Blitar.

\section{B. Metode Penelitian}

Penelitian ini menggunakan metode penelitian kualitatif dengan pendekatan studi kasus. Metode studi kasus memungkinkan peneliti untuk tetap holistik dan signifikan. Menurut Moleong penelitian kualitatif adalah penelitian yang bermaksud untuk memahami fenomena tentang apa yang dialami oleh subjek penelitian misalnya perilaku, persepsi, motivasi, tindakan dan lain-lain, secara holistik, dan dengan cara deskripsi dalam bentuk kata-kata dan bahasa, pada suatu konteks khusus yang alamiah dengan memanfaatkan berbagai metode alamiah ${ }^{4}$. Metode penelitian kualitatif dengan pendekatan studi kasus dianggap paling tepat dalam memaparkan

\footnotetext{
${ }^{4}$ L.J Moleong, Metode Penelitian Kualitatif, Edisi Revisi. Bandung: PT Remaja Rosdakarya, 2011, 6.
} 
program siaran interaktif sebagai ruang publik untuk meningkatkan kualitas pelayanan publik di kota Blitar dengan studi kasus Program Lang Lang Kota Radio Mayangkara FM Blitar.

Teknik pengumpulan data yang digunakan adalah rekaman arsip, wawancara, observasi langsung. Hal ini dilakukan karena dianggap paling relevan sebagai teknik pengumpulan data utama dan menjadikan lainnya sebagai pendukung. Teknik pengolahan data yang digunakan adalah pemeriksaan data, klasifikasi data dan punyusunan data. Data yang terkumpul melalui tahap seleksi dimana data dipilih yang berkaitan dengan permasalahan yang dikaji serta dihubungkan dengan metode kualitatif. Dalam penelitian ini metode pemeriksaan keabsahan data yang digunakan adalah triangulasi. Dalam hal ini peneliti mengunakan triangulasi teknik dan triangulasi sumber. Triangulasi teknik yang berarti peneliti menggunakan teknik pengumpulan data yang berbeda-beda untuk mendapatkan data dari sumber yang sama, dimana peneliti akan melakukan pengamatan di lapangan (observasi), wawancara mendalam, dan dokumentasi terhadap sumber data yang sama secara serempak. Sedangkan triangulasi sumber berarti, peneliti mendapatkan data dari sumber yang berbeda-beda dengan teknik yang sama melalui kegiatan wawancara mendalam.

\section{Diskusi}

\section{Profil Pogram Lang Lang Kota Radio Mayangara FM}

Radio Mayangkara merupakan salah satu radio swasta terbesar di Kota Blitar yang tergabung dalam jaringan bisnis Mayangkara Group. Berdiri pada tanggal 3 Juli 1987 sebagai Radio Siaran Non pemerintah atau (RSNP) pertama di Blitar yang beralamatkan di Jalan Ciliwung 32A Kota Blitar Jawa Timur. Nama Radio Mayangkara berasal dari cerita pewayangan Ramayana. Dikisahkan pada masa itu Resi Mayangkara adalah penjelmaan dari Hanoman (seekor kera putih). Hanoman dikenal sebagai panglima perang yang gagah berani, tokoh yang paling panjang usianya karena hidup dari zaman Ramayana sampai Mahabarata. Selain dari kisah pewayangan, Mayangkara juga diambil dari nama Kuda Putih tunggangan Mayor Djarot Soebyantoro. Mayor Djarot adalah pemimpin pasukan/batalyon 503 saat agresi militer Belanda pada tahun 1946 di Lamongan, Jawa Timur. Kuda putih menjadi

64 | Komunitas Vol. 11, No. 1 (2020) 
lambang kesatuan Batalyon 503. Atas dasar alasan tersebut dan saran dari Soeroto yang merupakan ahli bahasa Jawa sekaligus tokoh masyarakat Blitar sehingga Haryanto memilih nama Radio Mayangkara.

Masa kejayaan Radio Mayangkara terus berlanjut dengan melahirkan produkproduk acara unggulan radio diantaranya Galih Ratna, Rockarama, Pantun Berjoget, Gempil, dan Kejarama. Bahkan di tahun 1993 Radio Mayangkara menjadi radio swasta pertama yang berani membuat program berita produksi sendiri, diantaranya Lintas Kabar Mayangkara (Lintarama), Pilihan Kabar Minggu Ini (Pilar Mini), dan Rona Desa (Ronde).

Seiring perkembangan zaman dan kemajuan teknologi, agar lebih memberikan kepuasan pendengar, pada tahun 2000 Radio Mayangkara beralih mengudara pada Frekuensi Modulasi (FM). Momen itu bertepatan pasca lengsernya era orde baru dan munculnya era reformasi, dimana masyarakat lebih menginginkan transparansi dan kebebasan dalam berekspresi atau berpendapat. Peristiwa itu pun mendorong Radio Mayangkara tampil dengan karakter siaran baru dan beda, format radio berita "news interaktif " dengan label "Lang Lang Kota"

Dengan demikian, format siaran request (salam dan musik) ditanggalkan berganti menjadi format news interaktif. Pergeseran ini dianggap sebagai strategi yang tepat mengingat industri media dan hiburan terus berkembang dengan kehadiran internet. Program Lang Lang Kota (LLK) pun bersinergi dengan masyarakat dan pemerintah agar memposisikan diri sebagai media massa yang kritis dan solutif terhadap permasalahan di Blitar Raya dan sekitarnya. Perubahan format juga membawa konsekuensi pada strategi dalam pengemasan konten acara agar tetap menarik minat pendengar dan para pengiklan.

Dengan segmentasi usia pendengar pada range 20 tahun ke atas Radio Mayangkara juga memutarkan lagu-lagu hits mulai dari oldies sampai lagu hits terbaru. Selain kekuatan berita lokal dan dan nasional, lagu merupakan kekuatan radio untuk menarik pendengar sehingga para pemasang iklan tertarik untuk memasang iklan di radio tersebut. Sebagai radio swasta, iklan menjadi penopang bagi keberlangsungan operasional perusahaan. Berbagai produk iklan yang disajikan diantaranya iklan produk komersial dari perusahaan swasta baik lokal maupun 
nasional dan iklan berisi informasi yang berasal dari instansi pemerintahan Blitar Kota dan Kabupaten dan sekitarnya.

Sebagai program utama atau unggulan Lang Lang Kota (LLK) mengudara sejak pukul 06.00-21.00. Dalam setiap siarannya, para penyiar memberikan topik (aktual, hangat, sedang menjadi pembicaraan) baik dalam skala lokal maupun nasional, kemudian pendengar bisa menyampaikan pesan berupa argumen, kritik, ataupun gagasan terkait dengan topik yang sedang dibicarakan melalui telepon atau media sosial berupa whatsaap, instagram dan Facebook mayangkara. LLK juga mengandalkan kekuatan citizen journalism yang mana warga sebagai informan atau reporter. Hal ini sekaligus mengatasi keterbatasan penyiar atau gatekeeper dalam menjangkau semua informasi.

Menghadapi era digital, Radio Mayangkara pun menghadirkan berbagai terobosan dan kreativitas dalam penyajian program LLK, seperti live facebook, instagram, konten vlog dan sebagainya. Namun kreativitas tersebut tetap sesuai dengan kaidah jurnalistik dan fungsi media. Berkaitan fungsi informasi, Radio Mayangkara juga mengemas beberapa paket berita diantaranya Jurnal Warta berisi rangkuman liputan reporter dan editorial redaksi yang disiarkan pada pukul 06.0008.00. Kemudian pada pukul 06.30 liputan live reporter dari pasar-pasar yang ada di wilayah BLitar yang diberi nama Kabar Pasar, untuk mengabarkan fluktuasi harga sembako di wilayah Blitar Raya. Ada juga Info Kriminal dan Hukum yang merupakan rangkuman liputan reporter untuk kejadian-kejadian yang berada di ranah kriminal dan hukum. Acara tersebut disiarkan pada pukul 08.00 dan 20.00.

Tak ketinggalan ada juga paket berita yang diberi nama Jaring Informasi Mayangkara Group (JIM) yang berisi liputan reporter Mayangkara Radio Group wilayah Blitar dan Tulungagung dan disiarkan minimal lima kali dalam sehari bahkan bisa lebih jika ada peristiwa terkini. Ada juga Lang Lang Kota Hari ini sebagai rangkuman informasi yang telah disampaikan pendengar Mayangkara pada Program Lang Lang Kota. Up date informasi tiap menit ke 45 dalam paket berita Lintas Informasi Mayangkara (LIM) dan Tahukah Anda tiap menit ke 30. Selain paket-paket berita tersebut juga terdapat dialog non komersial dan dialog bersponsor.

66 | Komunitas Vol. 11, No. 1 (2020) 
Beragam paket berita tersebut bertujuan untuk semakin menguatkan peran Radio Mayangkara sebagai radio kontrol sosial sekaligus mendorong partisipasi masyarakat (citizen journalism) dalam program Lang Lang Kota untuk meningkatkan layanan publik yang berkualitas di wilayah Blitar dan sekitarnya. Berdasarkan pemaparan diatas, berikut ini alur dari Operasional Siaran Lang Lang Kota Radio Mayangkara FM :

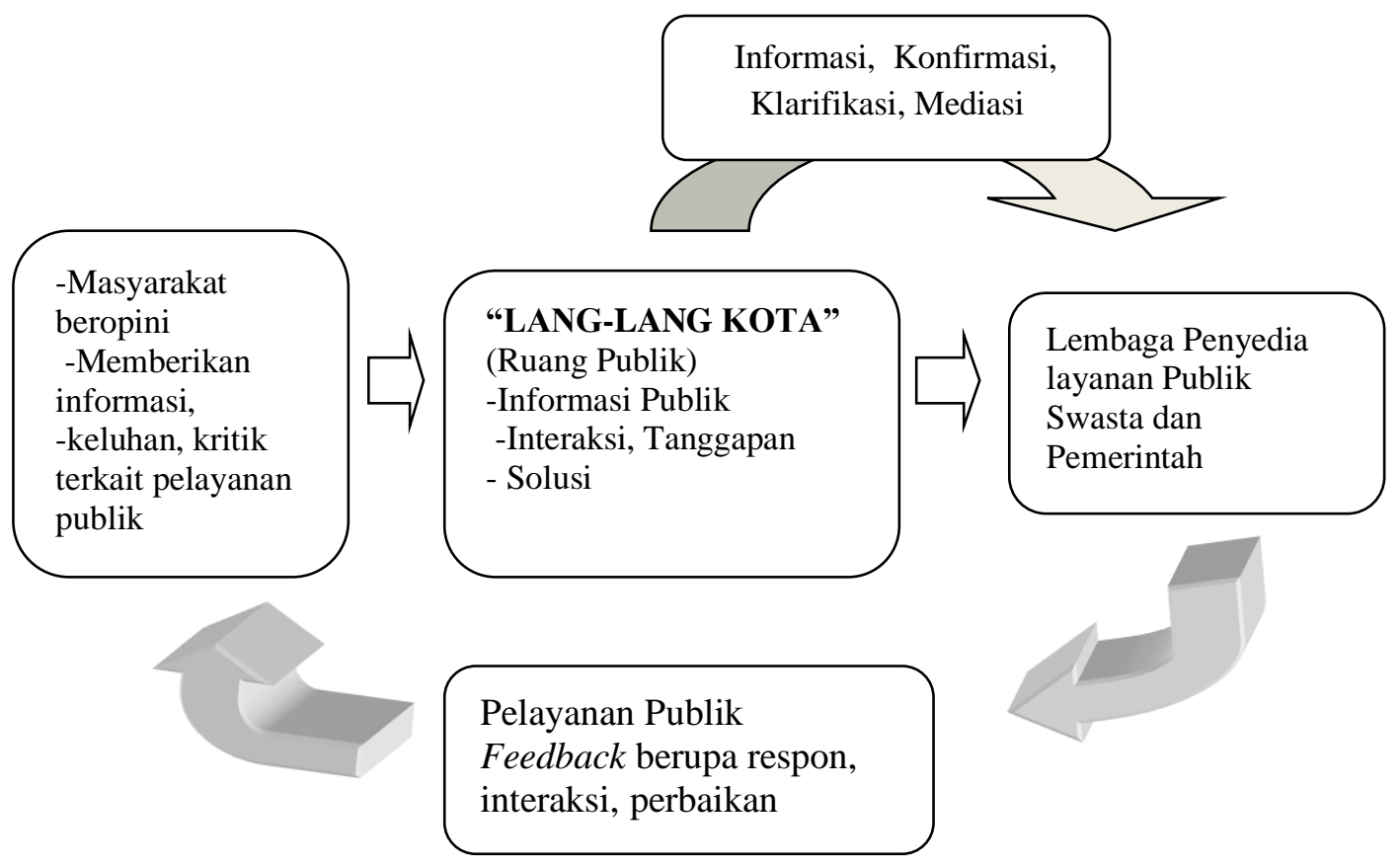

\section{Analisis Bentuk Ruang Publik Pada Siaran Interaktif Lang Lang Kota Radio Mayangkara FM}

Ruang publik sesuai pemikiran Habermas ${ }^{5}$ adalah ruang dimana perdebatan kritis tentang kepentingan publik yang terkait hubungan negara dengan masyarakatnya terjadi. Perdebatan itu terjadi jika kekuasaan di dalam ruang publik terdistribusi dengan merata pada anggota-anggotanya, tidak ada dominasi kekuasaan dan setiap orang dapat mengekspresikan pemikirannya. Tanpa kehadiran ruang

${ }^{5}$ Jurgen Habermas, The Structural Transformation of the Public Sphere. (trans) Thomas Burger, Britain: Polity Press, 1989.

Komunitas Vol. 11, No. 2 (2020) | 67 
publik komunikasi antara masyarakat dan pemerintah akan terhambat. Ruang publik dapat terwujud melalui media massa. Hal tersebut menjadi bagian dari proses demokratisasi dan penguatan civil society yang menjembatani hubungan antara rakyat dan pemerintahan. Fungsi media dalam ruang publik hanya akan maksimal jika media bersifat independen, tidak ada pengaruh atau intervensi dari siapapun.

Perwujudan ruang publik pada Radio Mayangkara FM melalui Program acara Lang Lang Kota (LLK) lahir dari keinginan untuk terus bersuara tentang apa yang terjadi di kota Blitar dan sekitarnya. Siaran interaktif LLK menggambarkan adanya interaksi antara penyiar dengan pendengar, penyiar dengan narasumber bahkan bisa berlangsung secara bersama-sama antara penyiar, pendengar dan narasumber. Dalam siaran live interaktif, pendengar ikut terlibat atau berperan aktif dalam memberikan informasi. Berdasarkan hasil wawancara secara mendalam dan observasi langsung, konsep citizen journalism yang telah diterapkan sejak awal terbentuknya Lang Lang Kota sebagai ruang publik sangat efektif untuk menarik audience sebanyak-banyaknya dan membuat masyarakat lebih peka terhadap apa yang terjadi di sekitar mereka, termasuk tentang kualitas pelayanan publik. Konsep citizen journalism dapat dikatakan berhasil ketika pendengar bersedia untuk menyampaikan berita tersebut baik on air by phone /GSM online atau pun melalui Sort Message Service (SMS), whatsaaap, facebook atau Instagram.

Dalam siaran interaktif tersebut tidak hanya antara penyiar dan pendengar, juga terjalin komunikasi antara antara penyiar dengan narasumber. Narasumber berasal dari tokoh, instansi terkait pelayanan publik/swasta, LSM, dan sebagainya. Narasumber bisa datang ke studio atau hanya melalui jaringan telepon, hal ini disesuaikan dengan situasi dan kebutuhannya. Jika diperlukan dalam kasus tertentu dapat mempertemukan narasumber dan pendengar untuk on air, dengan menggunakan fasilitas telephone hybrid. Dalam siaran interaktif LLK ada beberapa tahapan yang harus dipersiapkan penyiar dan gatekeeper sebagai ujung tombak siaran interaktif LLK sebagai berikut:

68 | Komunitas Vol. 11, No. 1 (2020) 
1. Sebelum bertugas, Penyiar harus memiliki topik siaran yang disebut rewrite, bisa didapatkan dari informasi masyarakat, internet, dan berita reporter. Penyiar juga harus mengetahui perkembangan informasi yang sudah terdata di ruang gatekeeper, menyampaikan up date informasi dan mampu membawakan live interaktif baik dengan pendengar ataupun narasumber

2. Gatekeeper harus selalu mencatat dan mendata informasi yang masuk ke lang lang kota, up date informasi, klarifikasi, konfirmasi dan berkomunikasi dengan penyiar. Setelah selesai bertugas juga

3. mengkomunikasikan tugas berikutnya pada gatekeeper selanjutnya.

4. Bagi semua petugas gatekeeper, saat menerima telepon kata kunci yang disampaikan "Salam...Nama (Radio Mayangkara )..ada yang bisa kami bantu“, kemudian menanyakan nama alamat penelpon, maksud dan tujuan yang ingin disampaikan, ketika menutup telepon jangan lupa menyampaikan ucapan terimakasih dan salam.

Sebagai radio news interaktif, para penyiar dan gatekeeper juga harus menyesuaikan diri, terutama dari segi kemampuan dan wawasan, karena mereka harus mengetahui beragam permasalahan terkait pelayanan publik di wilayah Blitar dan bersinergi dengan instansi atau lembaga penyedia pelayanan publik. Keberhasilan media penyiaran sejatinya ditopang oleh kreativitas manusia yang bekerja pada tiga pilar utama yang dimiliki setiap media penyiaran, yaitu teknik, siaran dan administrasi ${ }^{6}$. Maka eksistensi sebuah radio tidak terlepas dari program dan penyiar radio. Menurut Romli penyiar adalah orang yang bertugas membawakan atau memandu acara di radio, penyiar menjadi ujung tombak radio dalam berkomunikasi atau berhubungan langsung dengan pendengar ${ }^{7}$. Sebagai pilar utama dalam media penyiaran, maka penyiar harus bisa membawakan acara atau program radio dengan baik, karena inilah kunci kesuksesan sebuah program sehingga menarik minat pendengar. Bahkan seorang penyiar menjadi icon radio karena ciri khas yang dimilikinya dan mudah dikenali oleh pendengar.

Poin berikutnya mengenai bahan pembicaraan atau tema yang akan diangkat dalam siaran LLK. Sesuai dengan kebijakan redaksi LLK harus mengutamakan topik yang aktual-hangat sedang terjadi, memiliki news value dan kelokalan yang kuat,

\footnotetext{
${ }^{6}$ Morissan, Manajemen Media Penyiaran, Strategi Mengelola Radio, dan Televisi, Jakarta: Kencana, 2011, 133.

${ }^{7}$ Asep Syamsul M Romli, Dasar - Dasar Siaran Radio Basic Announcing. Bandung: Nuansa, $2009,37$.
} 
pelayanan publik, informasi ringan namun menarik dan menambah pengetahuan masyarakat, juga informasi nasional ataupun internasional, yang berdampak bagi masyarakat Blitar.

Radio Mayangkara mengalokasikan waktu siaran dengan sistem block time, pergantian penyiar setiap dua jam sekali. Pada jam prime time radio, pagi misalnya antara jam 06.00-10.00, topik yang disampaikan penyiar sangat berpengaruh terhadap ramai atau tidaknya komentar ataupun tanggapan dari pendengar pada jamjam siaran berikutnya. Hal tersebut didukung adanya Paket Berita Bincang Pagi yang tayang pada jam 07.30-07.45. Bincang Pagi adalah siaran interaktif by phone antara narasumber dengan penyiar yang berisi topik terhangat, aktual, menjadi perbincangan masyarakat baik dari lokal Blitar maupun nasional. Kondisi arus lalu lintas dan cuaca menjadi tema wajib bagi para penyiar dalam siaran interaktif Lang Lang Kota untuk menyapa para pendengarnya. Selain itu ada tema khusus yang diangkat sebagai topik siaran, berikut beberapa contoh isu-isu terhangat yang muncul pada jam prime time 06.00-10.00 pada tanggal 26 Desember 2019 - 04 Januari 2020.

\section{Tabel 1: Aduan dan Informasi Lang lang Kota}

(Sumber: Laporan Masyarakat LLK)

\begin{tabular}{|c|l|}
\hline \multicolumn{1}{|c|}{ TANGGAL } & \multicolumn{1}{|c|}{ TOPIK SIARAN } \\
\hline 26 Desember 2019 & $\begin{array}{l}\text { Tes Psikologi untuk Penerbitan SIM, } \\
\text { Pengamanan Jelang Tahun Baru }\end{array}$ \\
\hline 27 Desember 2019 & $\begin{array}{l}\text { Razia miras di Kebon Rojo dan TMP. } \\
\text { Penambahan videotron di Kota Blitar, menelan } \\
\text { anggaran hampir 1,5 Milyar }\end{array}$ \\
\hline 28 Desember 2020 & $\begin{array}{l}\text { Razia miras di sejumlah toko dan warung di } \\
\text { Blitar, Jalan rusak dan berlubang padahal baru } \\
\text { dibangun di Kota Blitar }\end{array}$ \\
\hline 30 Desember 2019 & $\begin{array}{l}\text { Kekerasan seksual terhadap anak, Penyegelan } \\
\text { tempat karaoke yang menjual miras tanpa izin } \\
\text { Bangunan Pasar Kanigoro, kios bocor sebelum } \\
\text { ditempati, Harga sembako jelang tahun baru }\end{array}$ \\
\hline 31 Desember 2019 & $\begin{array}{l}\text { Menghadapi cuaca ekstrim, Pembangunan Fiber } \\
\text { Optic di Kota Blitar membahayakan pengguna } \\
\text { jalan, Pemadaman Listrik }\end{array}$ \\
\hline
\end{tabular}

70 | Komunitas Vol. 11, No. 1 (2020) 


\begin{tabular}{|l|l|}
\hline 01 Januari 2020 & $\begin{array}{l}\text { Banjir lbukota, Antisipasi bencana longsor di } \\
\text { beberapa kawasan di Blitar, Kecelakaan lalu } \\
\text { lintas }\end{array}$ \\
\hline 02 Januarai 2020 & $\begin{array}{l}\text { Penertiban Bangunan DAS di kota Blitar dan } \\
\text { Parkir liar merajalela, Sampah, Banjir }\end{array}$ \\
\hline 03 Januarai 2020 & $\begin{array}{l}\text { Tingginya angka perceraian di Blitar Raya, } \\
\text { Kenaikan BPJS Kesehatan }\end{array}$ \\
\hline 04 Januarai 2020 & PDAM, Penertiban PKL, Konflik Natuna \\
\hline
\end{tabular}

Setiap topik yang disampaikan penyiar dalam siaran Lang Lang Kota sangat berpengaruh terhadap animo masyarakat untuk berkomentar atau bergabung baik secara on air melalui telepon ataupun melalui pesan singkat di media sosial mayangkara. Namun ada juga masyarakat yang memberikan informasi baru tidak sesuai topik siaran. Semua pesan yang masuk dan penelpon yang bergabung akan diterima gatekeeper. Gatekeeper berfungsi sebagai filter atau penyaring sebelum informasi tersebut disampaikan ke masyarakat. Gatekeeper seringkali harus memperhalus atau merubah kalimat yang disampaikan masyarakat melalui whatsaap atau media sosial. Namun perubahan itu tanpa mengurangi maksud yang disampaikan pengirim tersebut dan sesuai kaidah dan etika penyiaran publik. Sementara untuk penelpon yang menyampaikan komentar on air, biasanya mereka telah menjalin komunikasi dengan gatekeeper tentang informasi yang akan disampaikan.

Sesuai dengan slogan Radio Mayangkara kritis solutif bahwa semua informasi yang membutuhkan tanggapan, klarifikasi ataupun keluhan tentang pelayanan publik, diupayakan pada saat itu juga mendapatkan respon dari pihak terkait. Hal ini menghindari sebutan Lang Lang Kota sebagai "tempat sampah" tanpa ada solusi. Meskipun faktanya masih ada juga pejabat atau instansi terkait yang kurang kooperatif terkesan menghindar bahkan enggan memberikan informasi yang dibutuhkan masyarakat.

Seperti disampaikan Kabag Pemberitaan Radio Mayangkara untuk menyikapi berbagai permasalahan yang mengemuka di "ruang publik" tentu ada halhal yang menjadi prioritas, misalnya terkait insiden seperti kecelakaan, kebakaran.

Komunitas Vol. 11, No. 2 (2020) | 71 
Namun ada juga persoalan yang belum mampu terselesaikan pada saat itu juga ketika on air, sehingga peran reporter untuk melakukan investigasi atau penelusuran lebih lanjut. Dalam mendalami informasi atau laporan tersebut ada dua reporter yang berperan sesuai wilayah liputan masing-masing di Kota Blitar. Koordinasi antara tim yang berada di studio dan reporter di lapangan harus dilakukan agar mendapatkan hasil maksimal.

Menghadapi persaingan di era digital, satu hal yang tetap dipertahankan Radio Mayangkara yaitu loyalitas pendengar atau masyarakat. Keberadaan data base pendengar bisa digunakan untuk mengetahui respon pendengar terhadap program siaran, membangun kedekatan antara penyiar dan pendengar, kepentingan acara yang bersifat on air ataupun off air karena Radio Mayangkara adalah radio swasta yang tentu berorientasi pada profit. Kegiatan itu diantaranya Wisata Tombo Ati Radio Mayangkara, Pengobatan Gratis Radio Mayangkara, Managemen Emosional Spiritual Mayangkara (MESM).

Dengan demikian peneliti menyimpulkan bahwa dalam siaran interaktif Lang Lang Kota Radio Mayangkara, masyarakat selaku pengguna layanan publik memiliki kebebasan dalam berpendapat, menyampaikan opini ataupun kritikan terhadap instansi atau lembaga penyedia layanan publik. Namun kebebasan itu harus tetap bertanggungjawab sesuai fakta dan kebijakan redaksi LLK. Seperti konsep Habermas bahwa ruang publik itu sangat penting dalam menyemai demokrasi yang menjembatani kepentingan masyarakat dan penguasa. Dalam hal ini, pemilik Radio Mayangkara dan pemimpin redaksi Lang Lang Kota menjadi ujung tombak dalam mengambil kebijakan agar media tetap memposisikan diri netral dari kepentingan penguasa.

\section{Analisis Proses Komunikasi Antara Masyarakat dan Instansi/Lembaga Penyedia Layanan Publik Pada Siaran Interaktif Lang Lang Kota}

Berdasarkan paradigma Laswe $\|^{8}$ bahwa proses komunikasi terbagi menjadi dua tahap, yaitu:

a. Proses komunikasi secara primer

${ }^{8}$ Onong Uchjana Effendy, IImu Komunikasi: Teori dan Praktek. Bandung: PT Remaja Rosdakarya, 1994.

72 | Komunitas Vol. 11, No. 1 (2020) 
Proses komunikasi secara primer adalah proses penyampaian pikiran dan atau perasaan seseorang kepada orang lain dengan menggunakan lambang sebagai media. Diantaranya melalui bahasa, isyarat, gambar, warna dan lain sebagainya. Pada proses komunikasi secara primer, bahasa yang paling banyak digunakan, sebab bahasa mampu menerjemahkan pikiran seseorang kepada orang lain, apakah itu berbentuk ide, gagasan, informasi atau opini. Komunikasi berlangsung apabila terjadi kesamaan makna dalam pesan yang diterima oleh komunikan.

b. Proses komunikasi secara sekunder

Proses komunikasi secara sekunder adalah proses penyampaian pesan oleh komunikator kepada komunikan dengan menggunakan alat atau sarana sebagai media kedua setelah memakai lambang sebagai media pertama. Penggunaan alat atau sarana tersebut untuk melancarkan komunikasi karena komunikannya berada relatif jauh atau berjumlah banyak. Contoh dalam penggunaan telepon, surat, surat kabar, radio, majalah, televisi, dan banyak lainnya. Peranan media sekunder ini agar efektif dan efisien dalam menjangkau komunikan.

Dalam penelitian ini, peneliti telah melakukan wawancara dan observasi pada beberapa lembaga penyedia layanan publik di Kota Blitar, diantaranya Dinas Pekerjaan Umum dan Perumahan Rakyat (Dinas PUPR) Kota Blitar, Dinas Perhubungan Kota Blitar dan Bakesbangpol dan BPD (Badan Penanggulangan Bencana) Kota Blitar. Pemilihan narasumber/ informan tersebut didasarkan atas informasi dari tim gatekeeper Radio Mayangkara bahwa rentang waktu penelitian antara Nopember 2019 sampai Januari 2020, lembaga tersebut menerima banyak laporan dan keluhan dari masyarakat. Proses komunikasi ini termasuk dalam kategori komunikasi sekunder melalui media radio. Dalam proses komunikasi masyarakat dengan lembaga/instansi pelayanan publik tersebut, Lang Lang Kota berperan sebagai berikut:

1. Forum Terbuka untuk Menyampaikan Informasi, Aspirasi, Kritik dan Tanggapan 
Dalam hal siaran interaktif Lang Lang Kota (LLK) sebagai forum terbuka dalam menerima aspirasi pendengar, media publikasi, memberikan kritikan dan tanggapan terhadap beragam informasi atau permasalahan yang disampaikan masyarakat. Menurut Kabag Pemberitaan Radio Mayangkara kecepatan dan responsive dalam menanggapi apa yang disampaikan masyarakat menjadi salah satu jurus dalam mempertahankan kepercayaan masyarakat pada LLK. Adakalanya sebuah persoalan tidak bisa selesai saat itu juga, karena harus melibatkan berbagai pihak. Untuk itu ada beberapa program sebagai tindak lanjut dalam menanggapi sebuah kasus atau permasalahan yang menjadi bahasan utama di LLK.

Salah satunya Fokus Potret Kita (FPK), setiap hari kamis pukul 10.00, yang menghadirkan pihak-pihak terkait dan membuka kesempatan bagi masyarakat untuk bergabung menanggapi topik yang dibahas. Seperti pada bulan November 2019, Fokus Potret Kita membahas penggunaan trotoar sebagai tempat berjualan PKL yang semakin merajalela di berbagai kawasan di Kota Blitar. Padahal sudah ada tempat khusus yang diperuntukkan bagi PKL. Kemudian persoalan lain yang dikeluhkan masyarakat tentang bantuan pangan non tunai. Penyaluran bangtuan tersebut sering mengalami kendala dan tidak tepat sasaran. Minimnya sosialisasi dari pemerintah dan ketidakpahaman warga membuat keresahan di kalangan penerima bantuan pangan non tuani yang notabene mereka adalah warga tidak mampu.

Lang Lang Kota menjadi forum bagi siapapun yang ingin menyatakan argumen dan sikap mengenai layanan publik dan berbagai permasalahan lainnya. Sebagai tempat bertemunya berbagai kepentingan media harus tetap menjaga netralitasnya Seperti ditegaskan oleh Habermas bahwa ruang publik tersebut harus bebas dari intervensi dan ketidaktransparanan serta terbebas dari ruang negara.

2. Penanganan Laporan atau Keluhan Masyarakat oleh Instansi atau Lembaga Penyedia Layanan Publik 
Adanya ruang publik pada media massa menurut Jurgen Habermas memiliki andil dalam pembentukan opini publik. Peran vital media ini seharusnya bisa dimaksimalkan oleh lembaga atau instansi penyedia layanan publik untuk mengetahui opini atau aspirasi masyarakat demi meningkatkan kualitas layanan publik. Lang Lang Kota sebagai ruang publik telah mempertemukan kepentingan tersebut. Contoh laporan atau keluhan yang muncul pada program Lang Lang Kota dan tindak lanjut yang diberikan penyedia layanan publik adalah sebagai berikut:

\section{Balapan liar yang meresahkan warga}

Maraknya balapan liar yang terjadi di beberapa kawasan di Kota Blitar seperti di JI Sudanco Supriyadi atau di depan Taman Makam Pahlawan, Jalan Merdeka membuat resah masyarakat, Warga minta agar kepolisian tindak tegas mereka. Hal ini dapat dilihat dari aduan yang masuk pada LLK pada tanggal 30 Desember 2019 dan 02 Januari 2020 sebagai berikut:

"Mohon di tertibkan dini hari tadi balapan liar di depan TMP, banyak yang tidak pakai helm dan menganggu pengguna jalan yang lain "(dari Pak Anam warga Bendogerit)

"Pak polisi, tolong ditindak tegas balapan liar, kenapa kok dibiarkan saja, saya sudah beberapa kali melihat mereka dulu yang biasanya di jalan kenari" (dari Bu Ida warga Sananwetan)

Berdasarkan informasi dari tim gatekeeper Radio Mayangkara, balapan liar sejak bulan Desember kembali marak terjadi di kota Blitar, Polres Kota Blitar yang menerima pengaduan itu kembali mengintesifkan razia balapan liar dan patroli. Kasat Lantas Polres Blitar Kota, AKP Haris Dharma Sucipto melakukan razia atau Operasi Cipta Kondisi pada Minggu 5 Januari 2020 dinihari, di sekitar Jalan A. Yani \& Jalan S. Suprijadi kota Blitar sering dijadikan arena balap liar. Dari 4 operasi itu polisi mendapati ada 35 bikers yg tengah melakukan balap liar di lokasi. Dengan kondisi sepeda motor yg di modifikasi \& tidak sesuai standar. Selain sanksi pembinaan, para bikers itu diminta membuat surat pernyataan tidak mengulangi perbuatannya lagi. Razia 
Redi Panju

itu akan rutin gelar guna deteksi dini gangguan Keamanan serta ketertiban masyarakat khususnya pada malam hari.

2. Jalan licin rawan jatuh dan kecelakaan

Pasca hujan deras yang mengguyur kawasan Kota Blitar pada hari Jumat 1 Nopember 2019 sejumlah ruas jalan di Kota Blitar licin dan membuat pengendara sepeda motor jatuh, seperti di perempatan jalan Jenderal Sudirman atau sebelah utara Polres Blitar Kota. Hal itu juga disebabkan banyak bekas buah beringin yang jatuh di aspal kemudian nempel di roda. Beberapa laporan masyarakat diterima tim gatekeeper LLK dan media sosial mayangkara. Peristiwa itu langsung disampaikan pada Dinas Lingkungan Hidup Kota Blitar dan ditindaklanjuti dengan pembersihan bersama Damkar Kota Blitar.

Lang Lang Kota sebagai ruang publik mendorong adanya komitmen pemerintah atau lembaga penyedia layanan publik dalam menanggapi pengaduan atau keluhan masyarakat. Komitmen itu didasarkan pada UUD 1945 dan diperjelas kembali dalam UU No. 25 tahun 2009 tentang Pelayanan Publik yang mengatur prinsip-prinsip pemerintahan yang baik agar fungsifungsi pemerintahan berjalan efektif.

\section{SIMPULAN}

Berdasarkan hasil analisa data dan pembahasan tersebut maka disimpulkan bahwa program siaran interaktif Lang Lang Kota merupakan ruang publik, masyarakat bebas menyampaikan informasi, opini, keluhan, kritikan dan masukan berkaitan dengan layanan publik. Begitu juga sebaliknya bagi lembaga penyedia layanan publik dapat memanfaatkan media sebagai sarana berkomunikasi dengan warga untuk menanggapi keluhan atau pengaduan mengenai layanan publik yang telah diterima. Peran serta dan kepedulian masyarakat terhadap layanan publik menjadi salah satu kekuatan dalam siaran interaktif Lang Lang Kota, dengan menggunakan model citizen journalism. Hal ini juga menjadi tantangan bagi tim gatekeeper dan penyiar sebagai ujung tombak dalam melakukan filter (menyaring) informasi atau keluhan yang disampaikan masyarakat terkait layanan publik.

76 | Komunitas Vol. 11, No. 1 (2020) 
Kebebasan dalam bersuara pada ruang publik Lang Lang Kota tetap harus didasarkan pada kaidah jurnalistik. Media berperan dalam mengedukasi masyarakat. Setiap permasalahan atau aduan tentang layanan publik yang muncul harus disikapi dengan kritis dan menghasilkan solusi sehingga menghindari sebutan Lang Lang Kota sebagai keranjang sampah masalah. Untuk memaksimalkan hal tersebut dibutuhkan kerjasama dan sinergi antara tim pemberitaan dan tim penyiaran Radio Mayangkara. Program Lang Lang Kota menjadi contoh dari proses demokrasi lokal di kota Blitar. Keberlangsungan hal itu sangat tergantung dari netralitas redaksi Radio Mayangkara dan tidak adanya campur tangan dari penguasa.

Berdasarkan penelitian yang telah dilakukan, saran peneliti adalah sebagai berikut:

a. Bagi institusi media, Radio Mayangkara

1. Berdasarkan hasil observasi dan wawancara dengan para pendengar, diharapkan Program Lang Lang Kota lebih kritis dan lebih gencar lagi dalam menjalankan fungsinya sebagai lembaga kontrol sosial pada lembaga/instansi publik di Kota Blitar untuk meningkatkan kualitas layanan publik di kota Blitar.

2. Program Lang Lang Kota dapat bekerjasama dengan anak-anak muda untuk lebih mengencarkan lagi citizen journalism dengan konsep vlog atau melalui instagram.

3. Penyiar maupun gatekeeper sebagai garda terdepan dalam penyiaran harus lebih proaktif dan responsif dalam menyampaikan informasi dan menanggapi laporan LLK. Jika membutuhkan klarifikasi dan konfirmasi harus dilakukan dengan cepat kemudian disampaikan di udara atau on air karena suara adalah kekuatan radio.

4. Meningkatkan kualitas seluruh jurnalis yang ada di Radio Mayangkara dalam bidang pemberitaan dan memperkuat pengelolaan medsos mayangkara.

b. Bagi para peneliti 
Redi Panju

Penelitian ini dapat dijadikan sebagai bahan rujukan bagi penelitian selanjutnya, mengenai ruang publik di media massa (radio). Dan diharapkan lebih meningkatkan ketelitian dalam kelengkapan data penelitian.

\section{DAFTAR PUSTAKA}

Effendy, Onong Uchjana. (1994). Ilmu Komunikasi: Teori dan Praktek. Bandung: PT Remaja Rosdakarya

Habermas, J. (1989). The Structural Transformation of the Public Sphere. (trans) Thomas Burger, Britain: Polity Press.

Habermas, J. (1996). Between fact and norm, diterjemahkan oleh William Rehg, The MIT press, New Baskerville.

Hardiman, F.B. (2009). Demokrasi Deliberatif: Menimbang 'Negara Hukum' dan 'Ruang Publik' dalam Teori Diskursus Jurgen Habermas, Yogyakarta: Kanisius.

Moleong, L.J (2011). Metode Penelitian Kualitatif, Edisi Revisi. Bandung: PT Remaja Rosdakarya.

McQuail, Denis. (2000). Mass Communication Theory. London: Sage.

Morissan. (2011). Manajemen Media Penyiaran, Strategi Mengelola Radio, dan Televisi, Jakarta: Kencana.

Panuju, R. (2018). Pengantar Studi Ilmu Komunikasi. Jakarta: Kencana Prenada Mediagroup.

Romli, Asep Syamsul M. (2009). Dasar - Dasar Siaran Radio Basic Announcing. Bandung: Nuansa.

Rochmad Effendy, "Program Siaran Interaktif (Talk Back Radio) Sebagai Ruang Publik Masyarakat Untuk Mengembangkan Demokrasi Lokal: Studi Pada Program "Citra Publika" Radio Citra 87,9 FM Kota Malang" dalam Jurnal komunikasi, Vol. 9, No 1, Yogyakarta: Universitas Islam Indonesia, Oktober 2014.

Antonius Galih Prasetyo, "Menuju Demokrasi Rasional: Melacak Pemikiran Jurgen Habermas tentang Ruang Publik" dalam Jurnal IImu Sosial dan IImu Politik, Vol.16, No.02, Yogyakarta: Universitas Gadjah Mada, November 2012.

Deny Wahyu Tricana, "Media Massa dan Ruang Publik (Public Sphere), Sebuah Ruang yang Hilang" dalam Jurnal Aristo, Ponorogo: Universitas Muhammadiyah Ponorogo, Desember 2013.

78 | Komunitas Vol. 11, No. 1 (2020) 